\title{
Early last glacial maximum in the southern Central Andes reveals northward shift of the westerlies at $\sim 39 \mathrm{ka}$
}

\author{
R. Zech ${ }^{1, *}$, J. Zech ${ }^{1}$, Ch. Kull ${ }^{1}$, P. W. Kubik ${ }^{2}$, and H. Veit ${ }^{1}$ \\ ${ }^{1}$ Geographical Institute, University of Bern, Bern, Switzerland \\ ${ }^{2}$ Ion Beam Physics, ETH Zurich, Zurich, Switzerland \\ *now at: Geological Institute, ETH Zurich, Switzerland
}

Received: 31 August 2010 - Published in Clim. Past Discuss.: 1 October 2010

Revised: 14 December 2010 - Accepted: 4 January 2011 - Published: 12 January 2011

\begin{abstract}
The latitudinal position of the southern westerlies has been suggested to be a key parameter for the climate on Earth. According to the general notion, the southern westerlies were shifted equatorward during the global Last Glacial Maximum (LGM: 24-18 ka), resulting in reduced deep ocean ventilation, accumulation of old dissolved carbon, and low atmospheric $\mathrm{CO}_{2}$ concentrations. In order to test this notion, we applied surface exposure dating on moraines in the southern Central Andes, where glacial mass balances are particularly sensitive to changes in precipitation, i.e. to the latitudinal position of the westerlies. Our results provide robust evidence that the maximum glaciation occurred already at $\sim 39 \mathrm{ka}$, significantly predating the global LGM. This questions the role of the westerlies for atmospheric $\mathrm{CO}_{2}$, and it highlights our limited understanding of the forcings of atmospheric circulation.
\end{abstract}

\section{Introduction}

The southern westerlies are an important driver for upwelling around Antarctica and deep ocean ventilation (Toggweiler et al., 2006). As atmospheric $\mathrm{CO}_{2}$ is constantly and naturally removed in large quantities by marine organisms, and the respired $\mathrm{CO}_{2}$ is accumulating in the deep ocean, changes in upwelling might have a substantial affect on the concentration of atmospheric $\mathrm{CO}_{2}$ and climate on Earth. It has been suggested that a more equatorward position of the westerlies during glacials resulted in a weakening of the northward Ekman transport of surface waters, reduced deep ocean ventilation, and low levels of atmospheric $\mathrm{CO}_{2}$ (Toggweiler et al.,

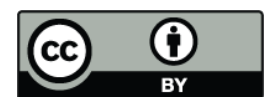

Correspondence to: $\mathrm{R}$. Zech (godotz@gmx.de)
2006). This hypothesis builds on the general notion that the westerlies were shifted northward during the global LGM, which has been inferred from terrestrial paleoecological and marine records off Chile (Heusser, 1989; Stuut and Lamy, 2004). However, there is a long-standing controversy regarding the interpretation of pollen records in Patagonia (Markgraf, 1989; Markgraf et al., 1992), and marine records may reflect a complex mixture of regional and local up-welling and environmental signals (Stuut et al., 2006). Additionally, climate modeling results do not show significant shifts of the westerlies during the global LGM (Rojas et al., 2008).

In order to contribute to the reconstruction of the position of the southern westerlies, we applied ${ }^{10} \mathrm{Be}$ surface exposure dating on moraines in the southern Central Andes. Whereas glaciers in Patagonia always received plenty of precipitation and reached their maximum extents at times of low temperatures, i.e. in-phase with the global LGM (Douglass et al., 2006; Kaplan et al., 2008), glacier mass-balances in more arid environments, such as the southern Central Andes, become more precipitation-sensitive, and the glacial chronologies there thus also reflect changes in the position of the westerlies (Kull et al., 2002, 2008, Wäger et al., unpublished manuscript).

\section{Geographical setting and surface exposure dating}

The southern Central Andes north of $\sim 40^{\circ} \mathrm{S}$ are characterized by strong precipitation gradients in north-south and eastwest directions (Fig. 1). They are therefore an ideal location to record latitudinal shifts of the westerlies. We applied ${ }^{10} \mathrm{Be}$ surface exposure dating in the Rucachoroi Valley, Central Argentina $\left(39^{\circ} 14^{\prime} \mathrm{S}, 71^{\circ} 11^{\prime} \mathrm{W}\right.$ ) (Fig. 2). The valley is located east of the Andean divide, but receives most of its precipitation from the Pacific related to the seasonal northward shift

Published by Copernicus Publications on behalf of the European Geosciences Union. 


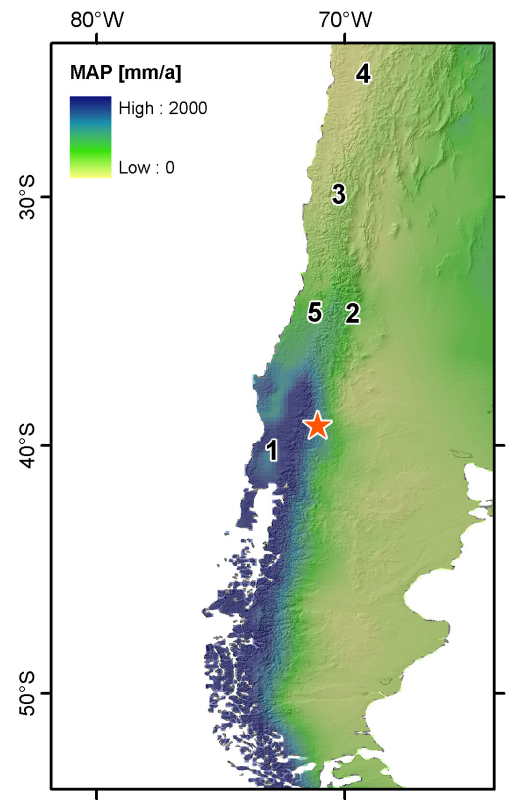

Fig. 1. Location of the research area, the Rucachoroi Valley (star), and other sites discussed in the text. 1 - Chilean Lake District, 2 Mendoza Andes, 3 - Cordon de Dona Rosa, 4 - Atacama Desert, 5 - Laguna Tagua Tagua. MAP = mean annual precipitation.

of the westerlies in austral winter (Garreaud and Aceituno, 2007). Weather station data from Bariloche $\left(41^{\circ} 15^{\prime} \mathrm{S}\right)$ indicate $\sim 800 \mathrm{~mm}$ mean annual precipitation with a pronounced austral winter maximum and $8^{\circ} \mathrm{C}$ mean annual temperature at $840 \mathrm{~m}$ above sea level (a.s.1.). No glaciers exist today in the Rucachoroi Valley despite summits reaching $>2000 \mathrm{~m}$ a.s.l. Extensive glaciation in the past is documented by the U-shaped valley form, glacial over-deepening (formation of Lake Rucachoroi at $1230 \mathrm{~m}$ a.s.l.), and a prominent right-lateral moraine merging into a lateral-frontal moraine at $\sim 1200 \mathrm{~m}$ a.s.l. (Fig. 2).

We sampled and analyzed seven boulders from the prominent lateral and lateral-frontal moraine in order to determine the timing of the maximum glaciation, as well as six additional boulders and polished bedrock from further up-stream to constrain the deglaciation history (Fig. 2). The sampling strategy followed standard guidelines, collecting $\sim 0.5 \mathrm{~kg}$ of rock material from the flat top of large, stable boulders or polished bedrock surfaces. Exact sample locations were determined using a handheld GPS and documented with photographs. Sample preparations followed standard laboratory techniques including separation of quartz, addition of a ${ }^{9} \mathrm{Be}$ carrier, dissolution in $\mathrm{HF}$, and chromatographical purification of beryllium. The ${ }^{10} \mathrm{Be} /{ }^{9} \mathrm{Be}$ AMS measurements were conducted at the ETH AMS facility in Zurich. We used the CRONUS-Earth online calculator (http://hess.ess. washington.edu) applying the scaling model of Lifton et al. (2005) to calculate the surface exposure ages (all sample data are provided in the supplementary Table 1). Note that our conclusions are independent of the choice of the scaling model (see Supplement Table 2).

\section{Results}

The exposure ages from the moraines range from $30.2 \pm 3.0$ ka to $38.8 \pm 3.9 \mathrm{ka}$ (Fig. 2). The observed scatter mainly reflects geological uncertainties due to post-depositional processes, and the generally low probability of pre-exposure justifies the application of the "oldest age model" (Putkonen and Swanson, 2003; Zech et al., 2005). Following this concept, the oldest boulder from a moraine is the best available minimum estimate for the true deposition age, unless it is a statistical or stratigraphic outlier. Accordingly, we can infer that the maximum ice extent in the Rucachoroi Valley occurred at $\sim 39 \mathrm{ka}$, clearly pre-dating the global LGM.

The exposure ages of $17.9 \pm 1.8 \mathrm{ka}$ and $14.8 \pm 1.5 \mathrm{ka}$ from the samples RU31 and RU32 (Fig. 2) show that the glacier continued to occupy the upper part of the Rucachoroi Valley and started to retreat beyond the Rucachoroi Lake only after the global LGM. The absence of moraines other than the prominent ones dated to $\sim 39$ ka likely indicates that no prominent glacial re-advances occurred between $\sim 39 \mathrm{ka}$ and $\sim 18 \mathrm{ka}$. Deglaciation of the upper part of the Rucachoroi Valley occurred after $\sim 18 \mathrm{ka}$, and most of the valley became ice-free by $\sim 15.5 \mathrm{ka}$ (RU11: $15.5 \pm 1.5 \mathrm{ka}$, RU21: $15.5 \pm 1.5 \mathrm{ka}$ ). Only small, sporadic cirque moraines provide geomorphological evidence for minor glacial readvances and climate reversals during the Lateglacial. One respective exposure age of $12.2 \pm 1.2 \mathrm{ka}$ (RC12) has been obtained so far, but will have to be corroborated in future studies.

\section{Comparison with other paleoclimate proxies}

The early local LGM in the Rucachoroi Valley and deglaciation after $\sim 18 \mathrm{ka}$ is consistent with findings from the Chilean Lake District (CLD) (Fig. 1). There, extensive radiocarbon dating showed that the piedmont glaciers reached maxima at ca. 29.6, 26.9, 23.1, 21.0, 14.9 and $13.9{ }^{14} \mathrm{C} \mathrm{ka} \mathrm{BP}$ $(\sim 35,31,28,25,18$ and $17 \mathrm{cal} \mathrm{kaBP})$, with earlier advances being notably more extensive in the northern CLD (Denton et al., 1999; Lowell et al., 1995). Further north, in the Mendoza Andes ( $\left.\sim 33^{\circ} \mathrm{S}\right)$, Argentina, the 'Penitentes Till' is constrained by a minimum thermo-luminescence age of $31.0 \pm 3.1 \mathrm{ka}$, as well as a U/Th age of $38.3 \pm 5.3 \mathrm{ka}$ from travertine (Espizua, 2004). Ultimately, exposure ages from the Dona Rosa Valley $\left(\sim 31^{\circ} \mathrm{S}\right)$, northern Chile, have shown that the maximum datable advance there occurred at $\sim 39.0 \pm 4.1 \mathrm{ka}$ (Zech et al., 2007, 2008). Thus, in summary, there is inevitable evidence that the local LGM in the southern Central Andes from 30 to $40^{\circ} \mathrm{S}$ significantly predated the global LGM on both the western and eastern side of the divide. 


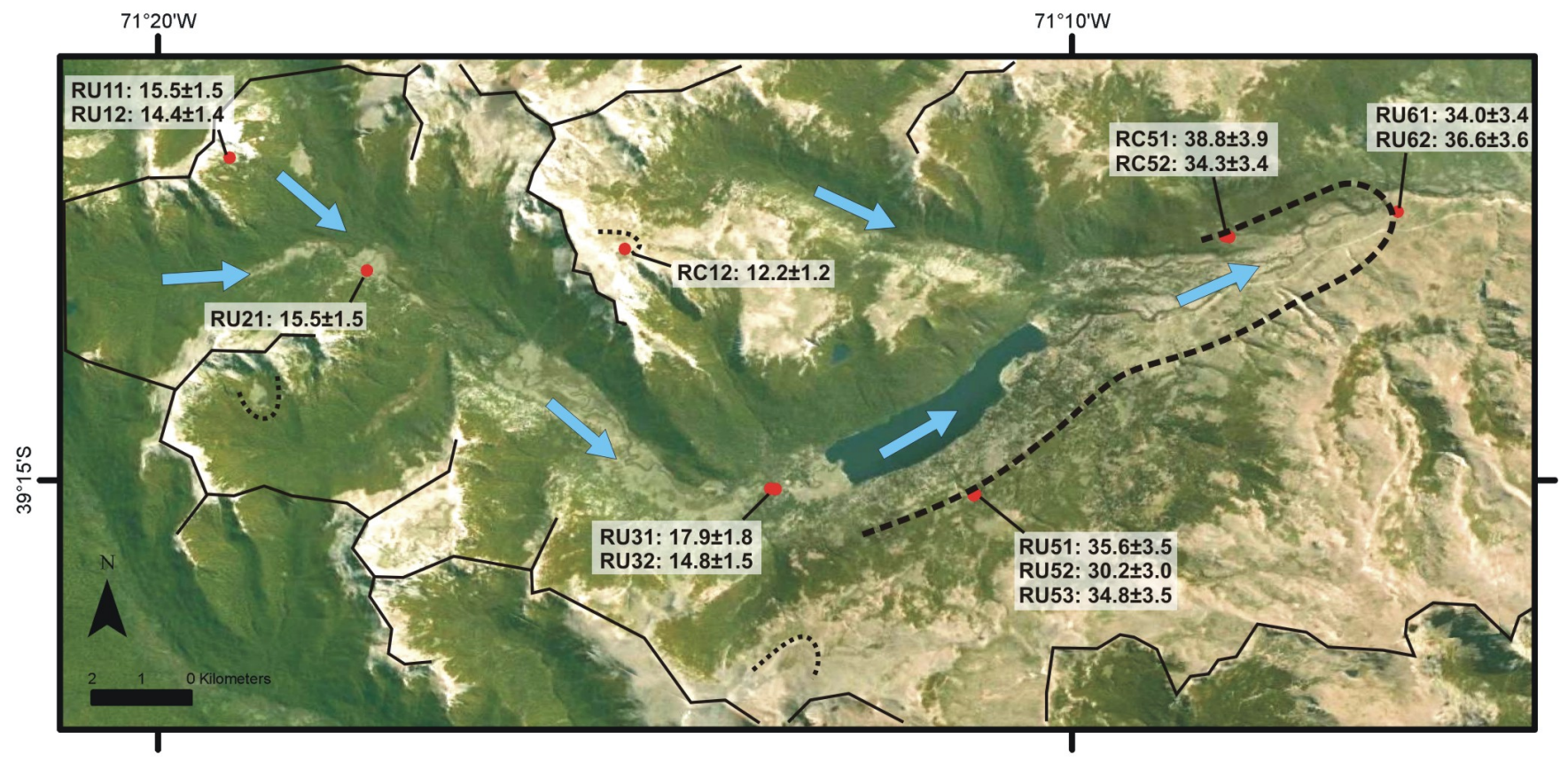

Fig. 2. Landsat image of the Rucachoroi Valley with sampling locations (red dots) and surface exposure ages [ka]. Blue arrows indicate the former ice flow direction, the dashed line marks the prominent lateral and lateral-frontal moraine, and dotted lines mark cirque moraines. Continuous thin lines demarcate the catchment crests.

We argue that this early LGM reflects increased precipitation and a northward shift of the westerlies, because glacier mass balance studies show that glaciers become very sensitive to changes in precipitation (rather than temperature) in arid and semiarid environments (Kull et al., 2002, 2008). This precipitation-sensitivity is evident today from the pronounced increases in equilibrium line altitudes from Patagonia to the Central Andes, as well as from contrasting glacial histories during the Little Ice Age, which have been explained with varying dominance of precipitation and temperature controls on mass balance (Luckman and Villalba, 2001). Analogously, differences in the timing of the glacial maxima during the last glacial have to be explained: Glaciers in Patagonia always received plenty of precipitation, are therefore mainly sensitive to temperature changes and reached their maximum extents in-phase with the global LGM at $\sim 25 \mathrm{ka}$ (Douglass et al., 2006; Kaplan et al., 2008). An early LGM in the more arid southern Central Andes, on the other hand, requires increased precipitation compared to the global LGM.

Our interpretation is corroborated by glacier-climate modeling results from the nearby Las Leñas Valley $\left(35^{\circ} \mathrm{S}\right)$, where the most extensive moraines (tentatively dated to $\sim 42 \mathrm{ka}$ based on preliminary exposure ages) were deposited under climate conditions much more humid than today $(60$ $150 \%$ increase in mean annual precipitation, $5.9-8^{\circ} \mathrm{C}$ decrease in mean annual temperature, Wäger et al., unpublished manuscript). Other, non-glaciological findings are also in agreement with this notion. Pollen records from $\sim 25^{\circ} \mathrm{S}$, for example, indicate increased winter precipitation between 40-33 $\mathrm{ka}$ and between 24-17 ka (Maldonado et al., 2005), and lake sediments from Central Chile show high lake levels of Laguna Tagua Tagua $\left(34.5^{\circ} \mathrm{S}\right)$ between $\sim 40$ and $17 \mathrm{ka}$ (Valero-Garcés et al., 2005). The circumpolar nature of the westerlies' shift should be investigated in more detail in the future, but extensive glacial advances, high lake levels and river runoff maxima are documented, for instance, also in southern Australia at $\sim 35 \mathrm{ka}$ (Barrows et al., 2001; Kemp and Spooner, 2007). There, an even more extensive glacial advance has been dated to $\sim 60 \mathrm{ka}$, which has not yet been identified in the southern Central Andes.

\section{Discussion of the forcings of the westerlies}

What does the proposed northward shift of the westerlies at $\sim 39 \mathrm{ka}$ mean in terms of our understanding of the forcings responsible for the latitudinal position of the southern westerlies? Traditionally, low Antarctic temperatures and extensive sea ice have been invoked to push the westerlies northward during the global LGM (Heusser, 1989; Stuut and Lamy, 2004). This is, however, difficult to fully reconcile with our findings, as neither sea ice was particularly extensive at $\sim 39 \mathrm{ka}$, nor were Antarctic temperatures at a minimum (Fig. 3a, c, e). Furthermore, we can rule out seasonal insolation/temperature as a prominent forcing, because winter insolation is high between $\sim 40$ and $20 \mathrm{ka}$ (Fig. 3d), which would favor a less pronounced seasonal northward shift of 
the westerlies and is at odds with more humid conditions documented for that very time period.

In search for other potential forcing mechanisms, we found an intriguing resemblance of the latitudinal position of the westerlies with changes in cosmic ray flux (Fig. 3b). High fluxes at $\sim 60 \mathrm{ka}$ and between $\sim 40$ and $25 \mathrm{ka}$, can be inferred from cosmogenic nuclides produced in the atmosphere, such as ${ }^{10} \mathrm{Be},{ }^{14} \mathrm{C}$ and ${ }^{36} \mathrm{Cl}$ (Christl et al., 2007; Hughen et al., 2004), and can be related to periods with a weaker geomagnetic field (e.g. the Laschamp event at $\sim 39 \mathrm{ka}$ ). Although admittedly highly speculative, we suggest that there might be causal linkages between past changes in the cosmic ray flux and the position of the southern westerlies. On the one hand, some scientists believe that cosmic-ray-induced ionization in the atmosphere can directly affect cloud formation and the atmospheric circulation (Burns et al., 2008; Usoskin and Kovaltsov, 2008). On the other hand, we point to a potential linkage via cosmic-ray-induced changes in the atmospheric chemistry, in particular ozone concentrations. Son et al. (2008), for example, have shown that the southward shift of the westerlies observed during recent decades can likely be attributed to the anthropogenic destruction of stratospheric ozone and related changes in temperature gradients. Provided that the Laschamp event also caused an ozone hole (Valet and Valladas, 2010; Vogt et al., 2009), one might analogously expect a southward shift of the westerlies at $\sim 39 \mathrm{ka}$. This, taken at face value, is the opposite of what one would expect from the apparent correlation between strong cosmic ray fluxes and northward shifts of the westerlies/glacial advances (Fig. 3a and b). We fully acknowledge that at this point we are unable to resolve this discrepancy, and we are curiously anticipating the results of a more sophisticated climate model that will couple atmospheric and ocean components and include cosmic ray-induced changes in atmospheric chemistry in the absence of anthropogenic chlorofluorocarbons. As such kind of modeling studies are still in their infancy, it is possible that the sign of the forcing might be different (Calisto, M., personal communication, 2010). If not, the uncertainties of the currently available glacial chronologies would also not rule out the possibility that the Laschamp event marks the end of the early LGM in the southern Central Andes rather than the glacial advance itself, and future studies may have to disentangle a complex mixture of forcings, including cosmic rays, Antarctic temperatures and sea ice.

\section{Conclusions}

The glacial chronologies in the southern Central Andes provide robust evidence for an early local LGM at $\sim 39 \mathrm{ka}$, which documents increased precipitation at that time and a northward shift of the southern westerlies. Our understanding of the forcings for this shift remains incomplete, and the coincidence with the Laschamp event will fuel discussions concerning possible cosmic ray - climate linkages. These

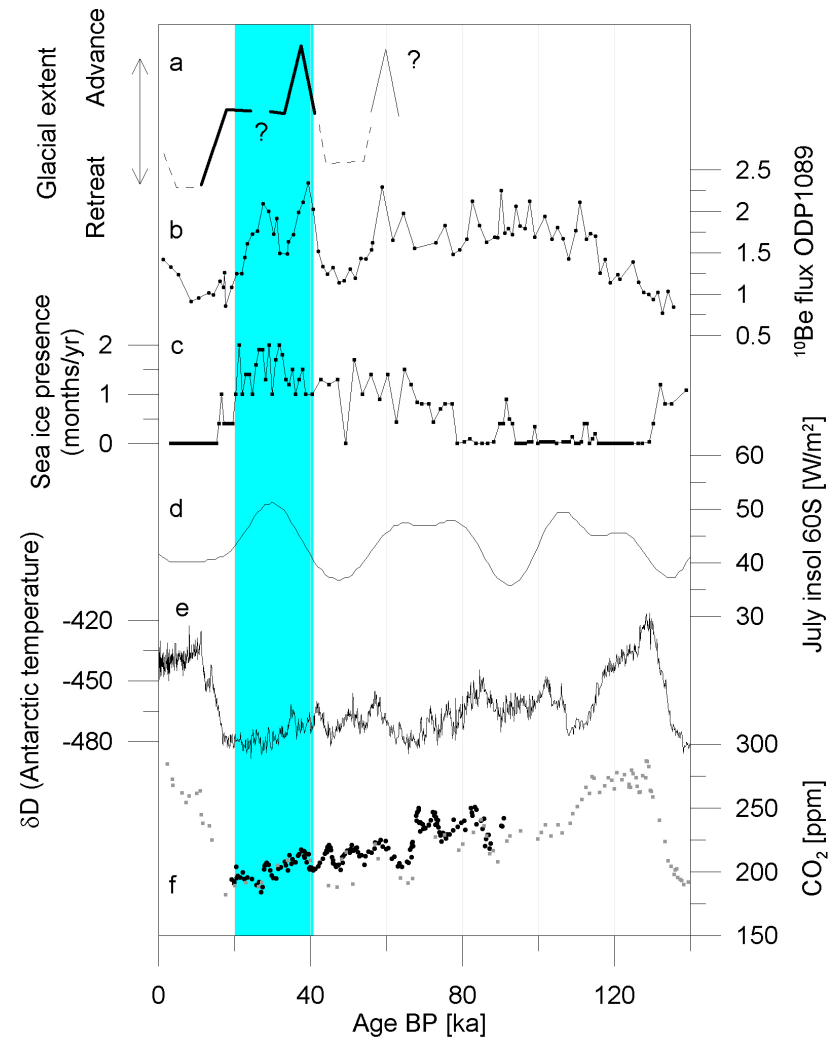

Fig. 3. Comparison of the glacial chronology in the southern Central Andes in the paleoclimatic context. (a) Glacial extents, indicating the northward shift of the westerlies, (b) changes in the cosmic ray flux (transport corrected ${ }^{10} \mathrm{Be}$ flux [at $\mathrm{cm}^{-2} \mathrm{kyr}^{-1}$ ] $\times 10^{9}$ ) (Christl et al., 2007), (c) sea ice duration around Antarctica (Crosta et al., 2004), (d) austral winter insolation at $60^{\circ} \mathrm{S}$, (e) deuterium from the Vostok ice core as proxy for Antarctic temperatures (Petit et al., 1999), and (f) atmospheric $\mathrm{CO}_{2}$ concentrations (Ahn and Brook, 2008; Petit et al., 1999).

linkages should be further investigated, and future global climate models might have to include cosmic-ray-induced changes in atmospheric chemistry.

Our findings also have major implications regarding the role of the westerlies in the carbon cycle. At first glance, low atmospheric $\mathrm{CO}_{2}$ concentrations between $\sim 40$ and $20 \mathrm{ka}$ seem to corroborate the proposed link between equatorward westerlies, reduced deep ocean ventilation, and low levels of atmospheric $\mathrm{CO}_{2}$ (Toggweiler et al., 2006). However, $\mathrm{CO}_{2}$ levels had already dropped significantly at $\sim 70 \mathrm{ka}$, and no dramatic changes occurred at $\sim 39 \mathrm{ka}$ (Fig. 3f) (Ahn and Brook, 2008). We conclude that latitudinal shifts of the westerlies did probably not exert dominant control on atmospheric $\mathrm{CO}_{2}$ concentrations on glacial-interglacial timescales, which is in agreement with recent modeling studies (Menviel et al., 2008; Tschumi et al., 2008). Other hypotheses should therefore be pursued, for example increased Southern Ocean stratification (Sigman et al., 2010) and changes in the terrestrial carbon cycle (Zech et al., 2010). 


\section{Supplementary material related to this article is available online at: http://www.clim-past.net/7/41/2011/ cp-7-41-2011-supplement.pdf.}

Acknowledgements. We thank M. Calisto, R. Toggweiler, M. Rojas, B. Tinsley and S. Son for stimulating discussions and the SNF for funding. R. Z. also acknowledges the support by the Studienstiftung des dt. Volkes. The Geological Department of the University of Bern granted access to the rock processing and clean lab facilities.

Edited by: C. Hatté

\section{References}

Ahn, J. and Brook, E. J.: Atmospheric $\mathrm{CO}_{2}$ and climate on millennial time scales during the last glacial period, Science, 322, 83-85, 2008.

Barrows, T. T., Stone, J. O., Fifield, L. K., and Cresswell, R. G.: Late Pleistocene Glaciation of the Kosciuszko Massif, Snowy Mountains, Australia, Quaternary Res., 55, 179-189, 2001.

Burns, G. B., Tinsley, B. A., French, W. J. R., Troshichev, O. A., and Frank-Kamenetsky, A. V.: Atmospheric circuit influences on ground-level pressure in the Antarctic and Arctic, J. Geophys. Res., 113, doi:10.1029/2007JD009618, 2008.

Christl, M., Mangini, A., and Kubik, P. W.: Highly resolved Beryllium-10 record from ODP Site 1089 - A global signal?, Earth Planet. Sci. Lett., 257, 245-258, 2007.

Crosta, X., Sturm, A., Armand, L., and Pichon, J.-J.: Late Quaternary sea ice history in the Indian sector of the Southern Ocean as recorded by diatom assemblages, Mar. Micropaleontol., 50, 209-223, 2004.

Denton, G. H., Lowell, T. V., Heusser, C. J., Schlchter, C., Andersen, B. G., Heusser, L. E., Moreno, P. I., and Marchant, D. R.: Geomorphology, stratigraphy, and radiocarbon chronology of Llanquihue drift in the area of the southern Lake District, Seno Reloncavi, and Isla Grande de Chiloe, Chile, Geogr. Ann., 81, 167-229, 2999

Douglass, D. C., Singer, B. S., Kaplan, M. R., Mickelson, D. M., and Caffee, M. W.: Cosmogenic nuclide surface exposure dating of boulders on last-glacial and late-glacial moraines, Lago Buenos Aires, Argentina: Interpretive strategies and paleoclimate implications, Quat. Geochronol., 1, 43-58, 2006.

Espizua, L. E.: Pleistocene glaciations in the Mendoza Andes, Argentina, in: Quaternary Glaciations - Extent and Chronology. Part III: South America, Asia, Africa, Australasia, Antarctica, edited by: Ehlers, J. and Gibbard, P. L., Elsevier, Cambridge, 2004.

Garreaud, R. and Aceituno, P.: Atmospheric circulation and climatic variability, in: The Physical Geography of South America, edited by: Veblen, T. T., Young, K. R., and Orme, A. R., 368 pp., Oxford University Press, Oxford, 2007.

Heusser, C. J.: Southern westerlies during the last glacial maximum, Quaternary Res. 31, 423-425, 1989.

Hughen, K., Lehman, S., Southon, J., Overpeck, J., Marchal, O., Herring, C., and Turnbull, J.: 14C Activity and Global Carbon
Cycle Changes over the Past 50000 Years, Science, 303, 202207, 2004.

Kaplan, M. R., Fogwill, C. J., Sugden, D. E., Hulton, N. R. J., Kubik, P. W., and Freeman, S. P. H. T.: Southern Patagonian glacial chronology for the Last Glacial period and implications for Southern Ocean climate, Quaternary Sci. Rev., 27, 284-294, 2008.

Kemp, J. and Spooner, N. A.: Evidence for regionally wet conditions before the LGM in southeast Australia: OSL ages from a large palaeochannel in the Lachlan Valley, J. Quaternary Sci., 22, 423-427, 2007.

Kull, C., Grosjean, M., and Veit, H.: Modeling Modern and Late Pleistocene Glacio-Climatological Conditions in the North Chilean Andes (29-30 $)$, Clim. Change, 52, 359-381, 2002.

Kull, C., Imhof, S., Grosjean, M., Zech, R., and Veit, H.: Late Pleistocene glaciation in the Central Andes: Temperature versus humidity control - A case study from the eastern Bolivian Andes $\left(17^{\circ} \mathrm{S}\right)$ and regional synthesis, Global Planet. Change, 60, 148164, 2008.

Lifton, N. A., Bieber, J. W., Clem, J. M., Duldig, M. L., Evenson, P., Humble, J. E., and Pyle, R.: Addressing solar modulation and long-term uncertainties in scaling secondary cosmic rays for in situ cosmogenic nuclide applications, Earth Planet. Sci. Lett., 239, 140-161, 2005.

Lowell, T. V., Heusser, C. J., Andersen, B. G., Moreno, P. I., Hauser, A., Heusser, L. E., Schlchter, C., Marchant, D. R., and Denton, G. H.: Interhemispheric correlations of Late Pleistocene glacial events, Science, 269, 1541-1549, 1995.

Luckman, B. H. and Villalba, R.: Assessing the Synchroneity of Glacier Fluctuations in the Western Cordillera of the Americas During the Last Millennium, in: Interhemispheric Climate Linkages, edited by: Markgraf, V., Academic Press, 2001.

Maldonado, A., Betancourt, J. L., Latorre, C., and Villagran, C.: Pollen analyses from a 50000 -yr rodent midden series in the southern Atacama Desert ( $25^{\circ} 30^{\prime}$ S), J. Quaternary Sci., 20, 493 507, 2005.

Markgraf, V.: Reply to C. J. Heusser's: Southern Westerlies during the Last Glacial Maximum, Quaternary Res., 28, 426-432, 1989.

Markgraf, V., Dodson, J. R., Kershaw, A. P., McGlone, M. S., and Nicholls, N.: Evolution of late Pleistocene and Holocene climates in the circum-South Pacific land areas, Clim. Dynam., 6, 193-211, 1992.

Menviel, L., Timmermann, A., Mouchet, A., and Timm, O.: Climate and marine carbon cycle response to changes in the strength of the Southern Hemispheric westerlies, Paleoceanography, 23, PA4201, doi:10.1029/2008PA001604, 2008.

Petit, J. R., Jouzel, J., Raynaud, D., Barkov, N. I., Barnola, J.-M., Basile, I., Bender, M., Chappellaz, J., Davis, M., Delaygue, G., Delmotte, M., Kotlyakov, V. M., Legrand, M., Lipenkov, V. Y., Lorius, C., Pepin, L., Ritz, C., Saltzman, E., and Stievenard, M: Climate and atmospheric history of the past 420000 years from the Vostok ice core, Antarctica, Nature, 399, 429-436, 1999.

Putkonen, J. and Swanson, T.: Accuracy of cosmogenic ages for moraines, Quaternary Res., 59, 255-261, 2003.

Rojas, M., Moreno, P., Kageyama, M., Crucfix, M., Hewitt, C., Abe-Ouchi, A., Ohgaito, R., Brady, E. C., and Hope, P.: The Southern Westerlies during the last glacial maximum in PMIP2 simulations, Clim. Dynam., 32, 525-548, doi:10.1007/s00382008-0421-7, 2009. 
Sigman, D. M., Hain, M. P., and Haug, G. H.: The polar ocean and glacial cycles in atmospheric $\mathrm{CO}_{2}$ concentration, Nature, 466, 47-55, 2010.

Son, S. W., Polvani, L. M., Waugh, D. W., Akiyoshi, H., Garcia, R., Kinnison, D., Pawson, S., Rozanov, E., Shepherd, T. G., Shibata, K.: The Impact of Stratospheric Ozone Recovery on the Southern Hemisphere Westerly Jet, Science, 320, 1486-1489, 2008.

Stuut, J.-B. W. and Lamy, F.: Climate variability at the southern boundaries of the Namib (southwestern Africa) and Atacama (northern Chile) coastal deserts during the last $120000 \mathrm{yr}$, Quaternary Res., 62, 301-309, 2004.

Stuut, J.-B. W., Marchant, D. R., Kaiser, J., Lamy, F., Mohtadi, M., Romero, O. E., and Hebbeln, D.: The Late Quaternary paleoenvironment of Chile as seen from marine archives, Geographica Helvetica, 61, 135-151, 2006.

Toggweiler, J. R., Russell, J. L., and Carson, S. R.: Midlatitude westerlies, atmospheric $\mathrm{CO}_{2}$, and climate change during the ice ages, Paleoceanography, 21, PA2005, doi:10.1029/2005PA001154, 2006.

Tschumi, T., Joos, F., and Parekh, P.: How important are Southern Hemisphere wind changes for low glacial carbon dioxide? A model study, Paleoceanography, 23, PA4208, doi:10.1029/2008PA001592, 2008.

Usoskin, I. G. and Kovaltsov, G. A.: Cosmic rays and climate of the Earth: Possible connection, Comptes Rendus Geosciences, 340, 441-450, 2008.
Valero-Garcés, B. L., Jenny, B., Rondanelli, M., Delgado-Huertas, A., Burns, S. J., Veit, H., and Moreno, A.: Palaeohydrology of Laguna de Tagua Tagua ( $\left.34^{\circ} 30^{\prime} \mathrm{S}\right)$ and moisture fluctuations in Central Chile for the last 46000 yr, J. Quaternary Sci., 20, 625641, 2005.

Valet, J.-P. and Valladas, H.: The Laschamp-Mono lake geomagnetic events and the extinction of Neanderthal: a causal link or a coincidence?, Quaternary Sci. Rev., 29, 3887-3893, 2010.

Vogt, J., Sinnhuber, M., and Kallenrode, M.-B.: Effects of Geomagnetic Variations on System Earth, in: Geomagnetic Field Variations, edited by: Gla $\beta$ meier, K.-H., Soffel, H., and Negendank, J. F. W., 159-208, Springer, 2009.

Zech, R., Glaser, B., Sosin, P., Kubik, P. W., and Zech, W.: Evidence for long-lasting landform surface instability on hummocky moraines in the Pamir Mountains from surface exposure dating, Earth Planet. Sci. Lett., 237, 453-461, 2005.

Zech, R., Kull, C., and Veit, H.: Exposure dating of Late Glacial and pre-LGM moraines in the Cordillera Dona Rosa, Northern Chile ( 31 ${ }^{\circ}$ S), Clim. Past 3, 1-14, 2007.

Zech, R., May, J.-H., Kull, C., Ilgner, J., Kubik, P., and Veit, H.: Timing of the late Quaternary glaciation in the Andes from $\sim 15$ to $40^{\circ} \mathrm{S}$, J. Quaternary Sci., 23, 635-647, 2008.

Zech, R., Huang, Y., Zech, M., Tarozo, R., and Zech, W.: Permafrost carbon dynamics explain atmospheric $\mathrm{CO}_{2}$ and the ice ages during the Pleistocene, Clim. Past Discuss., 6, 2199-2221, 2010 . 